\title{
Long-Standing Type-2 Diabetes Mellitus Is Related to Neuropathy Incidence: A Cross Sectional Study
}

\author{
Syamsiah ${ }^{1}$, Andi Baso Tombong ${ }^{2 *}$, Andi Nurlaela Amin ${ }^{3}$ \\ S1 Keperawatan Stikes Panrita Husada Bulukumba,Indonesia ${ }^{1}$ \\ Universitas Hasanuddin, Makassar, Indonesia ${ }^{2}$ \\ Departemen Keperawatan Medikal Bedah, Stikes Panrita Husada Bulukumba, \\ Indonesia ${ }^{3}$
}

*Corresponding Author: andibaso.tombong@unhas.ac.id

\begin{abstract}
Neuropathy has been associated with various risk factors, including increasing age, male gender, poor sugar consumption, lipid value index and blood pressure, duration and severity among patients with Diabetes Mellitus. In Bulukumba Regency, a report by the Bulukumba District Health Office reveals that there were 5410 visits of Diabetes Mellitus patients. This study aimed to identify the relationship between the long-standing Type-2 Diabetes Mellitus with neuropathy incidence among DM patients at H. Andi Sulthan Daeng Radja Hospital in Bulukumba Regency. This study that was conducted in July - August 2020, used a crosssectional design. The study involved 38 patients selected by employing the purposive sampling technique. In terms of duration since diagnosed Type-2 DM, there were 30 patients $(78.9 \%)$ included in the short-period category (1-5 years), and eight people (21.1\%) included in the long-period category. The proportion of respondents that experienced incidence of neuropathy are as follow: $5.3 \%$ (two patients) with mild neuropathy, 60.5\% (23 patients) with moderate neuropathy, and $34.2 \%$ (13 patients) with severe neuropathy. Bivariate analysis using Kolmogorov-Smirnov test results in p-value $=0.006(<\alpha=0.05)$. The research concludes that there is a significant relationship between the length of suffering of Type-2 Diabetes Mellitus and the incidence of neuropathy. It is recommended that Type-2 DM patients should be educated about the risk of developing neuropathy and its associated health consequences. Policies regarding the use and/ or development of neuropathy assessment within healthcare facilities are also encouraged to help healthcare professionals educate such patients to prevent the negative impact of diabetic neuropathy among DM patients in the future.
\end{abstract}

Keywords: Type-2 DM, Neuropathy, Incidence, Risk, Chronic 


\section{INTRODUCTION}

Diabetes Mellitus or commonly abbreviated to DM which is a chronic condition that can occur when a human body is unable to produce enough insulin or is unable to use insulin, and therefore can be characterized by increased levels of glucose in the blood (International Diabetes Federation, 2015 as cited in Taufiqur et al., 2017). The level of self-awareness is the main social determinant in the development of diseases that cause increased morbidity and mortality. In relation to DM, a wide range of research has reported that the level of such awareness depends on the class of social economy, the training received by them, and the source of information about diabetes. According to WHO (World Health Organization) to reduce the prevalence and incidence of diabetes and its complications, it is important to improve knowledge, attitudes and practices about Diabetes Mellitus (Bruce and Mallika, 2019).

In the WHO (World Health Organization) data center, Diabetes Atlas of 2015 from the IDF (Indonesian Development Forum) stated that among 220 countries around the world the prevalence of people with Diabetes Mellitus has been estimated to rise from 415 million people in 2015 to 642 million people in 2040. Nearly half of these are in Asia, namely China, India, Indonesia and Pakistan (Tandra, 2017). The NCDEG (National Center for Diabetes, Endocrinology and Genetics), a national and specialized referral outpatient center dealing with Diabetes Mellitus cases from all over Jordan and primarily serves a population of 4.1 million in Amman City, provides information about the majority of patients with Diabetes Mellitus in the city of Amman, including those with health insurance. More than 70\% of Jordanians have health insurance. In 2017, NCDEG recorded 116,226 patients. The patient's usual treatment involves regular follow-up every 3 months with weight, height and measurement of blood pressure, fundus and examina foot tions in addition to glycated hemoglobin (HbA1c). Annual evaluation of microvascular complications in addition to lipid profiles is a routine practice in all cases of Diabetes Mellitus in NCDEG centers (Khawaja et al., 2018).

In Indonesia, based on the RISKESDAS (Riset Kesehatan Dasar) in 2018, the prevalence of Diabetes Mellitus based on the diagnosis of doctors in the population aged $>15$ years is reported as much as $2.0 \%$ of the population in Indonesia. Meanwhile, burden of disease study in 2018 reported that DM sufferers increased by 157.1\%. By province, DKI Jakarta ranked first, accounting for $3.4 \%$ of the population of the 
province, and the lowest was East Nusa Tenggara province with which $0.9 \%$ of the population. South Sulawesi Province scored as much as $1.9 \%$ of the population(Kemenkes, 2018).

In Bulukumba Regency, based on the visit of Diabetes Mellitus patients that was reported by the Bulukumba District Health Office, the data shows that in 2019 as many as 5410 visits of diabetes mellitus disease (Bulukumba Health Office, 2019). At RSUD H. Andi Sultan Daeng Radja, the number of people with Diabetes Mellitus using insulin who were hospitalized in 2017 was 127 people, and without use of insulin as many as 91 patients. The outpatient data shows that Diabetes Mellitus patients who used insulin were as many as 17 people, and without with insulin were as many as 368 people. In 2018, the number of people with Diabetes Mellitus who were hospitalized using insulin were 141 ppatients, and who did not use insulin were 144 patients (RSUD H. Andi Sultan Daeng Radja Medical Records Unit, 2019).

According to the information center of the Indonesian Hospital Association data, the prevalence of patients with diabetes Mellitus with neuropathy complications is more than $50 \%$ of people with Diabetes Mellitus. The statement is reinforced by the results of Indonesia's Basic Health Research that shows the most common complications of Diabetes Mellitus which is neuropathy, and this is experienced by about $54 \%$ of patients (Rahman, 2017).

It is thought that there are several other factors underlying the occurence of neuropathy. Diabetic neuropathy is associated with a variety of risk factors including age, male sex, poor sugar level regulation, lipid value index and blood pressure, length and severity of patients with Diabetes Mellitus. Epidemiological studies show that uncontrolled sugar levels increase the risk of neuropathy (Parisi et al., 2016). Meanwhile, in Hutapea's research (2016) as cited in Rahman (2017) showed that the incidence of neuropathy of Diabetes Mellitus patients was found in many female patients, aged 45-65 years who has long suffered from Diabetes Mellitus for one to one and a half years.

The average duration of individuals with Diabetes Mellitus Type 2 who also developed neuropathy with long suffering is over 6 years with a range of age 50 years and above. According to the investigation conducted by Nurchalida (2015) asserts that long suffering from Type 2 diabetes was $>8$ years accounting for $72 \%$ and $<8$ years as 
much as $27 \%$ with an age range of more than 50 years. Restada research (2016) with an average suffering of 6-10 years was $36 \%$ with an average age of $>50$ years among 40 neuropathy sufferers. While the research of Komalasari (2018) indicated that long suffering from Diabetes Mellitus Type 2 among them 1-5 years and 6-10 years were $40 \%$ and $39 \%$ respectively. This proportion of neuropathy sufferers as much as $60 \%$ of the samples mostly occurred in patients aged more than 50 years old.

An initial observation conducted by this study researcher at RSUD H. Andi Sultan Daeng Radja obtained data that eight patients with Type-2 Diabetes Mellitus who underwent medical check up at the internal medicine outpatient clinic experienced neuropathy. There were six out of the eight patients who were complaining of rough skin which was starting to crack. In addition, researcher also noticed a thickening formation on the skin of the patients' feet. Among these six patients, five of them stated that when walking, the heel began to be insensitive compared to the previous condition or before developing Diabetes Mellitus. This is reinforced by the results of Khawaja and colleagues' research in Jordan in 2018, who found that in the past the strain of Type-2 Diabetes Mellitus was significantly associated with DPN or Diabetes Peripheral Neuropathy.

Long suffering from Diabetes Mellitus Type 2 is an onset where the first occurrence of hyperglycemia due to abnormalities of insulin secretion, the work of insulin and both that lasts 7 years before being diagnosed is established, until the occurrence of microvascular complications arising 15 years after diabetes mellitus (Komalasari, 2018). Diabetic neuropathy is one of the many complications that occur in people with type 2 diabetes mellitus. Diabetic neuropathy causes nerve damage especially in the legs and causes impaired walking function. Approximately $20-30 \%$ of type 2 diabetes mellitus patients suffer from neuropathic pain. People with type 2 diabetes mellitus who experience neuropathic pain have a low quality of life and are dependent on treatements that are expensive health costs (Juster, 2016). Based on these circumstances, researchers of this study were interested to conduct research at RSUD H. Andi Sultan Daeng Radja that focus on the incidence of Diabetes Mellitus disease in relatiuon to the incidence of neuropathy. This study assessed the duration of diabetes mellitus among patients hospitalized at the hospital and reviewed the incidence of neuropathy of such Diabetes Mellitus patients. 


\section{MATERIAL AND METODHS}

This study used cross sectional design, a non-experimental design often used to measure the relationship between free variables (risk factors) and effect variables by measuring the variables in a period of measurement (Sastroasma, 2014). The research was conducted in July-August 2020 at H.Andi Sultan Daeng Raja Hospital in Bulukumba Regency. The population in this study was all patients with Diabetes Mellitus Type 2 who were treated at H.Andi Sultan Daeng Radja Hospital as the target population. The population from November 2019 to January 2020 was 57. The size of the sample was determined using the formula developed by Sopiyudin Dahlan (2009) and resulted in 38 samples. The sampling method used non-probability sampling with Purposive Sampling technique. Instruments used were observation sheets to determine the duration of diabetes mellitus type-2, while questionnaire was employed to assess the incidence of neuropathy in patients.

The observation sheet contains the duration of Diabetes Mellitus Type-2, consisting of short duration (1-5 years), medium duration (6-10 years) and long duration ( $>10$ years). For observation sheets using the check sheet, the DNS Score Check Sheet (Diabetic Neuropathy Symptom).

\section{RESULTS}

Table 1.Distribution of Respondents' Frequency Based on Length of Suffering from DM Type 2

\begin{tabular}{ccc}
\hline Long Suffering from DM Type 2 & Frekuency (f) & Percentage (\%) \\
\hline Short Duration & 30 & 78,9 \\
Medium Duration & 8 & 21,1 \\
\hline Amount & 38 & 100 \\
\hline
\end{tabular}

The results of the study based on table 1 indicates that among 38 respondents in H.Andi Sultan Daeng Radja Hospital, there are the number of respondents with long suffering from DM Type 2 short duration proportion of 1-5 years as many as 30 people (78.9\%) compared to the medium duration of $6-10$ years, which is $21.1 \%$ (eight respondents).

Table 2. Distribution of Respondents' Frequency Based on Neuropathy Events

\begin{tabular}{ccc}
\hline Incidence of Neuropathy & Frekuency (f) & Percentage (\%) \\
\hline Mild Neuropathy & 2 & 5,3 \\
Moderate Neuropathy & 23 & 60,5 \\
Severe Neuropathy & 13 & 34,2 \\
\hline Amount & $\mathbf{3 8}$ & $\mathbf{1 0 0}$ \\
\hline
\end{tabular}


From the table, it can be seen that among 38 respondents in RSUD H. Andi Sultan Daeng Radja, there most dominant neuropathy incidence was moderate neuropathy, occured in 23 patients (60.5\%), followed by severe neuropathy as many as 13 patients (34.2\%), and mild neuropathy in two patients (5.3\%).

Table 3. Relationship Long-Standing Type-2 Diabetes Mellitus With Neuropathy Incidence

\begin{tabular}{|c|c|c|c|c|c|c|c|c|c|}
\hline \multirow{3}{*}{$\begin{array}{l}\text { Long Suffering from } \\
\text { DM Type } 2\end{array}$} & \multicolumn{8}{|c|}{ Incidence of Neuropathy } & \multirow{3}{*}{$P$ Value } \\
\hline & \multicolumn{2}{|c|}{$\begin{array}{c}\text { Mild } \\
\text { Neuropathy }\end{array}$} & \multicolumn{2}{|c|}{$\begin{array}{l}\text { Moderate } \\
\text { Neuropathy }\end{array}$} & \multicolumn{2}{|c|}{$\begin{array}{c}\text { Severe } \\
\text { Neuropathy }\end{array}$} & \multicolumn{2}{|c|}{ Amount } & \\
\hline & f & $\%$ & $\mathrm{f}$ & $\%$ & $\mathrm{f}$ & $\%$ & f & $\%$ & \\
\hline $\begin{array}{l}\text { Short Duration 1-5 } \\
\text { years }\end{array}$ & 2 & 6,7 & 22 & 73,3 & 6 & 20,0 & 30 & 78,9 & \\
\hline $\begin{array}{c}\text { Medium Duration 6-10 } \\
\text { years }\end{array}$ & 0 & 0 & 1 & 12,5 & 7 & 87,5 & 8 & 21,1 & 0,006 \\
\hline Amount & 2 & 5,3 & 23 & 60,5 & 13 & 34,2 & 38 & 100 & \\
\hline
\end{tabular}

Table 3 depicts the bivariate analysis of the data using Kolmogorov-Smirnov test. The results show a significant value of $\mathrm{p}=0.006$, indicating that the results was smaller than $\alpha=0.05$. This shows a significant relationship between long suffering from type 2 diabetes mellitus with the incidence of neuropathy among such patients hospitalized at RSUD H. Andi Sultan Daeng Radja in Bulukumba Regency.

\section{DISCUSSION}

The duration or length of DM diagnosis in this study was divided into three (3) categories or classifications where the most respondents were in the group of duration since diagnosed 1-5 years. The onset or the start of type 2 DM is 7 years before diagnosis was established. The diagnosis was supported by the criteria of type 2 DM with typical complaints of polydipsi, polyphagi and polyuri and was also supported by clinical blood glucose test results (Tsalissavrina, 2018).

According to Rusnani (2014), the duration of suffering from Type-2 DM is the onset of hyperglycemia that occurs due to abnormalities of insulin secretion, the work of insulin or both that lasts 7 years before the diagnosis is confirmed, until the occurrence of microvascular complications that arise 15 years after the first symptom develops. The duration of DM can be classified into a mild duration (1-5 years), a medium duration of 6-10 years and a long duration of more than 10 years. This study is in line with a 2016 study by Hutapea at RSUP Prof. Dr. R. D. Kandou conducted in 2014-2015, 
that found that based on the duration of Diabetes Mellitus Type-2, patients with duration 5 years and below was 62\%, while 6-10 years category accounted for $30 \%$.

In this study, the data of the incidence of neuropathy was obtained from assessment of the symptoms felt and experienced by respondents. The framework used was the Assessment of DNS (diabetic neuropathy Symptom). The impact of neuropathy is that there are risks associated with diabetes that result in proprioceptive disorders. One of them is diabetic neuropathy whose impact on the nervous system causes a slowdown in nerve transmission and reduced sensitivity. This results in numbness, tingling and pain in the legs, and increases the risk of damage to the skin due to loss of sensation and leads to sensory disorders including kinesthetic and proprioceptive. Diabetic neuropathy is a complication that causes loss of kinesthetic and proprioceptive sensations that have an important role in perception and stability. As a result it causes impaired perception and stability of the body to maintain its position (Komalasari, 2018).

This research is in line with research conducted by Suyanto in 2016 that showed that 75 respondents (94.9\%) had diabetic peripheral neuropathy. Based on this, the incidence of neuropathy can occur among diabetes mellitus and it can develop by the time since diagnosis is confirmed. Therefore, the risk of complications can also increase due to degenerative factors such as the decrease in human body function. One of the things we can know in Diabetes Mellitus Type 2 patients is that patients who have neuopathy ranging from mild, moderate to severe depends on the length of time the patient has diabetes. Sufferers from day to day will experience a lack of sensitivity especially in the legs when neuropathy is developing.

The significant correlation between long suffering from type 2 diabetes mellitus and the incidence of neuropathy shown by this study conforms Suyanto's theory (2016) that the longer patients have type- 2 diabetes mellitus, the higher the risk of incidence of complications. The duration of type 2 diabetes mellitus with high blood sugar levels will affect changes in the walls of blood vessels. According to Tanhardjo, et al (2016), chronic high blood sugar levels causes a decrease in insulin secretion. The glucose will turn into sorbitol which causes nerve cell damage. The longer a person suffers from DM, the longer this process will last and aggravates the occurrence of nerve cell damage.

In this study, the average length of time to suffer from type 2 diabetes mellitus is 5 
years and above, with the category of moderate neuropathy. There are some respondents with type-2 diabetes mellitus, which is 1-2 years old who have suffered from diabetes with mild neuropathy category. While the elderly with a long suffering of more than 5 years also have severe neuropathy. The results of this study are in accordance with several relevant studies which state that diabetic peripheral neuropathy experienced by DM patients occurs from 3 - 5 years after the disease was diagnosed (Tesfaye, 2006). Decreased nerve cell function can reduce foot sensation in the elderly. The results of the relevant study stated that elderly patients are strongly associated with decreased foot sensation in diabetic neuropathy patients ( $p$ value < 0.0001). Diabetic neuropathy generally occurs after 5 years of developing type 2 diabetes mellitus. Low glycemic control and dyslipidemia will increase the occurrence of diabetic neuropathy (Jaiswal et al., 2017).

The results of this study showed diabetic neuropathy complications suffered by respondents have occurred in a fairly shorter period of time after being diagnosed with type-2 diabetes mellitus. This can be seen from the long suffering from diabetes mellitus type-2 from respondents who are 1 year old, have already experienced mild neuropathy. The incidence of neuropathy is influenced by the age of respondents, there are elderly respondents who have only 1 year of diabetes mellitus since being diagnosed with mild neuropathy that have the potential to gradually experience more severe neuropathy. This can have a negative effect in the patient's health as many people with type- 2 diabetes mellitus have a low level of understanding about the disease and how it develops into several complications.

The study also confirms the research conducted by Darsana (2015) at Sanglah Denpasar Hospital that showed the significant correlation between long suffering from type-2 DM and the incidence of neuropathy. In azura MS et al.(2015) research, it was also reported that the clinical symptoms of neuropathy will increase with age. For every 1 year, clinical symptoms of neuropathy will appear 1.11 times in neuropathic patients compared to non-neuropathic patients. The results are also similar to the research that has been conducted by Hutapea (2016) who found that the most neuropathic patients are patients with long suffering from type-2 DM in the span of 1-5 years (52 respondents). The research conducted at RSUP Prof. Dr. R.D. Kandou Manado also indicated the most clinical symptoms, namely clinical symptoms of cramps, among 70 
patients (84.3\%).

The data of this of this study, mainly obtained from the patients are subjective so that the results of this research depends on the opinion of patients who experience symptoms of climatic neuropathy. According to Yang (2014) the research conducted is descriptive and retrospective, so to determine the symptoms and severity of neuropathy is quite difficult so that a diagnostic examination is needed that provides objective value to clinical symptoms experienced by patients, such as diabetic neuropathy symptom (DNS) and Diabetic Neuropathy Examination (DNE) scores. Both tests are scoring systems that use sophisticated tools with $96 \%$ sensitivity and 51\% specificity to neuropathic diagnosis (Lumbatobing, 2014). Although the limited number of respondents and research areas involving only one hospital, the incidence rate and length of suffering from type 2 diabetes mellitus has provided information about the association of the two variables and also credible data about this topic particularly in a regency that is far away from the big cities. This means that diabetes can cause neuropathy regardless the location of the patients with the disease. In addition, researchers asserts that long suffering from Diabetes Mellitus Type 2 patients has a factual risk of developing neuropathy. So it can be seen that an individual with type-2 diabetes mellitus is at very high risk of developing neuropathy.

\section{CONCLUSION}

The number of respondents with long-suffering Type $2 \mathrm{DM}$ is higher on the short duration criteria compared to moderate duration. The number of respondents based on the incidence of neuropathy was more on the moderate criteria than in the criteria of severe neuropathy and the criteria of mild neuropathy. There is a significant association between long suffering from type 2 diabetes mellitus and the incidence of neuropathy in patients hospitalized at H. Andi Sultan Daeng Radja Hospital in Bulukumba Regency with $\mathrm{p}$ value $=0.006$ smaller than $\alpha=0.05$. 


\section{REFERENCES}

Amalia, S.N. (2016). Studi Penggunaan Obat Analgesik Pada Pasien Diabetik Neuropati Di Rumah Sakit Universitas Airlangga (RSUA) Surabaya. Universitas Airlangga.

Azura MS, Adibah HI, Juwita S. 2015. Risk factor of peripheral neuropathy among newly diagnosed type 2 diabetic patients in primary care clinic. International Journal of Collaborative Research on Internal Medicine \& Public Health.

Bruce, M. \& Mallika, M. V. 2019. Prevalence of complications of diabetes among patients with diabetes mellitus attending a tertiary care centre in Tamil Nadu. International Journal of Community Medicine and Public Health.

Dahlan, Sopiyuddin, 2009. Besar Sampel Dan Cara Pengambilan Sampel Dalam Penelitian Kedokteran Dan Kesehatan. Edisi 2. Jakarta: Salemba Mediak.

Darsana IN, 2014. Korelasi positif kadar asam urat serum tinggi dengan neuropati diabetik perifer pada penderita DM tipe 2 di Rumah Sakit Umum Sanglah Denpasar [Tesis]. Denpasar: Universitas Udayana.

Decroli, E. (2019). Diabetes Mellitus Tipe 2. Jakarta: Pusat Penerbitan Bagian Ilmu Penyakit Dalam Fakultas Kedokteran Universitas Andalas Padang.

Dewi, N. K. \& Kusumaningrum, N. S. D. 2017. Hubungan Antara Foot Self-Care Dan Neuropati Perifer Pada Diabetisi. Faculty of Medicine.

Hidayat, A. A. (ed.) 2018. Metodologi Penelitian Keperawatan dan Kesehatan, Jakarta: Salemba Mediak.

Hutapea, Faisal S, dkk, 2016. Gambaran klinis neuropati pada pasien diabetes melitus di Poliklinik Neurologi RSUP Prof. Dr. R. D. Kandou periode Juli 2014 - Juni 2015. Jurnal e-Clinic (eCI), Volume 4, Nomor 1, Januari-Juni 2016

Irwan, M. d. (2019). Model Matematika Penyakit Diabetes. Jurnal Kesehatan UIN Alauddin Makassar .

Jaiswal, M., Divers, J., Dabelea, D., Isom, S., Bell, R. A., Martin, C. L., ... Marcovina, S. (2017). Prevalence of and risk factors for diabetic peripheral neuropathy in youth with type 1 and type 2 diabetes: search for diabetes in youth study. Diabetes Care, 40(9), 1226-1232. https://doi.org/10.2337/dc17-0179

Juster, K. e. (2016). Updates in diabetic peripheral neuropathy [version 1; referees: 3 approved]. F1000 Research, 5 (F1000 Faculty Rev):738 doi:10.12688/f1000research.7898.1).

Kurniawan, D. (2019). Panduan Praktik Klinis Neurologis. Jakarta: Perhimpunan Dokter Spesialis Saraf Indonesia (PERDOSSI). 
Kemenkes. (2018). Laporan Riset Kesehatan Dasar. Jakarta: Puslitbang Kemenkes RI. Khawaja, N. (2018). Prevalensi dan faktor risiko neuropati perifer antara pasien dengan diabetes mellitus tipe 2; kasus Jordan. Journal Diabetology \& Metabolic Syndrome https://doi.org/10.1186/s13098-018-0309-6.

Komalasari, D. R. 2018. Hubungan Lamanya Menderita Diabetes Mellitus Dengan Kejadian Diabetic Peripheral Neuropathy (DPN) Dan Resiko Jatuh Pada Pasien Diabetes Mellitus Tipe 2. Jurnal Ilmiah Fisioterapi (JIF), 1, 1-11.

Lumbantobing SM. Neurologi klinik pemeriksaan fisik dan mental (Cetakan 17). Jakarta: Balai Penerbit FKUI, 2014; p, 115-130

Maria Candida R et. all, P. (2016). Baseline characteristics and risk factors for ulcer, amputation and severe neuropathy in diabetic foot at risk: the BRAZUPA study. Diabetology \& Metabolic Syndrome Reseach .

Meijer, J., Smit, A., Sonderen, E., Groothoff, J., Eisma, W. \& Links, T. 2002. Symptom scoring systems to diagnose distal polyneuropathy in diabetes: the Diabetic Neuropathy Symptom score. Diabetic Medicine, 19, 962-965.

NIDDK. 2015. Diabetic Neuropathy [Online]. NIH. Available: https://www.niddk.nih.gov/health-

information/diabetes/overview/preventing-problems/nerve-damagediabetic-neuropathies [Accessed 27 Februari 2020].

Nuchalida, M. (2015). Hubungan Lamanya Menderita Diabetes Melitus Tipe 2 Dengan Penurunan Fungsi Kognitif. Surakarta: Fakultas Kedokteran Unismuh Surakarta.

Nursalam, 2009. Konsep dan Penerapan Metodologi Penelitian Ilmu Keperawatan. Jakarta : Salemba Medika

Praythiesh Bruce, V. M. (2019). Prevalence of complications of diabetes among patients with diabetes mellitus attending a tertiary care centre in Tamil Nadu. International Journal of Community Medicine and Public Health .

Rahman, T. (2017). Gambaran Kejadian Status Neuropati Perifer Pada Penyandang Diabetes Mellitus di Puskesmas Sukohardjo. Jurnal Kesehatan Unismuh Surakarta .

RSUD H.Andi Sultan Daeng Radja. (2018). Laporan Pasien Diabetes Mellitus Tahun 2017-2018. Bulukumba: Rekam Medik Rs H.A.Sultan Dg Radja.

Rahmawati, A. (2018). Faktor Dominan Neuropati Diabetik Pada Pasien Diabetes Melitus Tipe 2. Jurnal Berkala Epidemiologi Volume 6 Nomor 1 DOI: 10.20473/jbe.v6i12018.60-68, 60-68.

Restada, E. J. (2016). Hubungan Lama Menderita Dan Komplikasi Diabetes Melitus Dengan Kualitas Hidup Pada Penderita Diabetes Melitus Di Wilayah Puskesmas Gatak Sukoharjo. Surakarta: Laporan Akhir Unismuh Surakarta.

Riyanto, Agus, 2012. Pengolahan Dan Analisis Data Kesehatan. Yogyakarta: Nuha Medika. 
Rusnani, Fibriani, 2014. Diabetika Komplikasi Saraf pada Penderita Diabetes. Diabates Research Papers, Diabetika Publikasi.

Saryono. (2011). Metodologi Penelitian Kesehatan Penuntun Praktis Bagi Pemula. Jogjakarta: Mitra Cendikia.

Sastroasma, S. (2014). Dasar-Dasar Metodologi Penelitian Klinis, Edisi ke- 5. Jakarta: Sagung Seto.

Soegondo, S. d. (2018). Penatalaksanaan Diabetes Mellius Terpadu . Jakarta: Fakultas Kedokteran Universitas Indonesia.

Suyanto. (2016). Faktor-Faktor Yang Berhubungan Dengan Kejadian Neuropati Perifer Diabetik. Nurscope. Jurnal Keperawatan dan Pemikiran IImiah. 2 (6). , 1-7.

Tandra, H. (2017). Segala Sesuatu Yang Anda Harus Ketahui Tentang Diabetes. Jakarta: PT Gramedia Pustaka Utama.

Tanhardjo, J., Pinzon, R. T., \& Sari, L. K. (2016). Perbandingan rerata kadar HbA1c pada pasien diabetes melitus dengan neuropati dan tanpa neuropati sensori motor. Berkala IImiah Kedoteran Duta Wacana, 1(2), 127-136.

Taufiqur, R., Purwanti, O. S. \& S Kep, N. 2017. Gambaran Kejadian Status Neuropati Perifer Pada Penyandang Diabetes Mellitus Di Wilayah Kerja Puskesmas Sukoharjo. Universitas Muhammadiyah Surakarta.

Tegueu, K. e. (2015). Prevalence and determinants of diabetic polyneuropathy in asubSaharan African referral hospital. Journal of the Neurological Sciences .

Tesfaye, S. (2006). Diabetic neuropathy. In; Veves A, Giurini JM, LoGerfo FW, editor. The Diabetic Foot, Second Edition. New Jersey: Humaniora Press.

Tsalissavrina, Iva, dkk,2018. Hubungan Lama Terdiagnosa Diabetes Dan Kadar Glukosa Darah Dengan Fungsi Kognitif Penderita Diabetes Tipe 2 Di Jawa Timur. Jurnal AcTion: Aceh Nutrition Journal, Mei 2018; 3(1):28-33 . doi: 10.30867/action.v3i1.93

Yang Z, Chen R, Zhang Y, Huang Y, Hong T, Sun F, et al. 2014. Scoring system to screen for diabetic peripheral neuropathy. The Cocharane collaboration. John Wiley \& Sons,Ltd. Available from: cochranelibrary.com.

Wikibuku. (2019). Buku Saku Farmakoterapi/Neuropati Diabetik. Jakarta: Buku Bebas : Google Books 